\title{
An Examination of Six "Nutting Stones" from East Texas for Plant Phytoliths
}

Mark Walters

Heritage Research Center, Stephen F. Austin State University

Steven Bozarth

Thomas H. Guderjan

Follow this and additional works at: https://scholarworks.sfasu.edu/ita

Part of the American Material Culture Commons, Archaeological Anthropology Commons, Environmental Studies Commons, Other American Studies Commons, Other Arts and Humanities Commons, Other History of Art, Architecture, and Archaeology Commons, and the United States History Commons

Tell us how this article helped you.

This Article is brought to you for free and open access by the Center for Regional Heritage Research at SFA ScholarWorks. It has been accepted for inclusion in Index of Texas Archaeology: Open Access Gray Literature from the Lone Star State by an authorized editor of SFA ScholarWorks. For more information, please contact cdsscholarworks@sfasu.edu. 


\section{An Examination of Six “Nutting Stones” from East Texas for Plant Phytoliths \\ Creative Commons License \\ (c) (i) (8)}

This work is licensed under a Creative Commons Attribution-NonCommercial 4.0 International License 


\title{
An Examination of Six "Nutting Stones" from East Texas for Plant Phytoliths
}

\author{
Mark Walters, Steven Bozarth, and Thomas H. Guderjan
}

\section{INTRODUCTION}

In this article we report on an examination of six nutting stones from East Texas sites as well as an exploratory examination of their possible functions. "Nutting stones" have long been presumed to have been used prehistorically for crushing nuts such as hickory, etc. as foodstuffs. In fact Davis (1995:334) described them as being:

A small flat stone, usually made of limestone, sandstone or other sedimentary types of rock which could be carried by hand. The flat surface may have one or more ground or pecked cups of various sizes, shapes and depth. It is postulated that they were used for various purposes such as cracking nuts, mixing pigments, milling herbs and seeds, or as an anvil for flint knapping.

While Davis is an avocationalist and numerous professional archaeologists have dealt with nutting stones, we know of neither a more complete definition nor any other effort to empirically test for their function.

\section{NUTTING STONES}

The nutting stones are from the following East Texas sites in Smith and Camp counties in East Texas: Walters Farm (41SM194), Dead Cow (41SM324), Leaning Rock (41SM325), 41SM350, 41SM358, and Pilgrim's Pride (41CP304).

\section{Dead Cow (41SM324)}

The Dead Cow site is an early to mid-19th century archaeological site with a scatter of undated prehistoric lithic debris and a single ferruginous sandstone (FSS) pitted stone (Perttula 2011:31). This pitted stone, a surface find, is $10.0 \mathrm{~cm}$ in length, $7.0 \mathrm{~cm}$ in width, and $5.0 \mathrm{~cm}$ thick (Figure 1). It is smoothed on one side with a very shallow $2.0 \mathrm{~cm}$ diameter depression.

\section{SM350}

This is an undated Caddo habitation site in the eastern portion of Smith County, Texas. The example is a surface find near Unit 1. It is an oval-shaped FSS nutting stone, with one end broken. Both sides and the edges have been roughly shaped. The nutting stone is $10.0 \mathrm{~cm}$ in length, $8.5 \mathrm{~cm}$ in width, and $5.0 \mathrm{~cm}$ thick (Figure 2). There is a shallow $3.0 \mathrm{~cm}$ diameter depression on one side. 


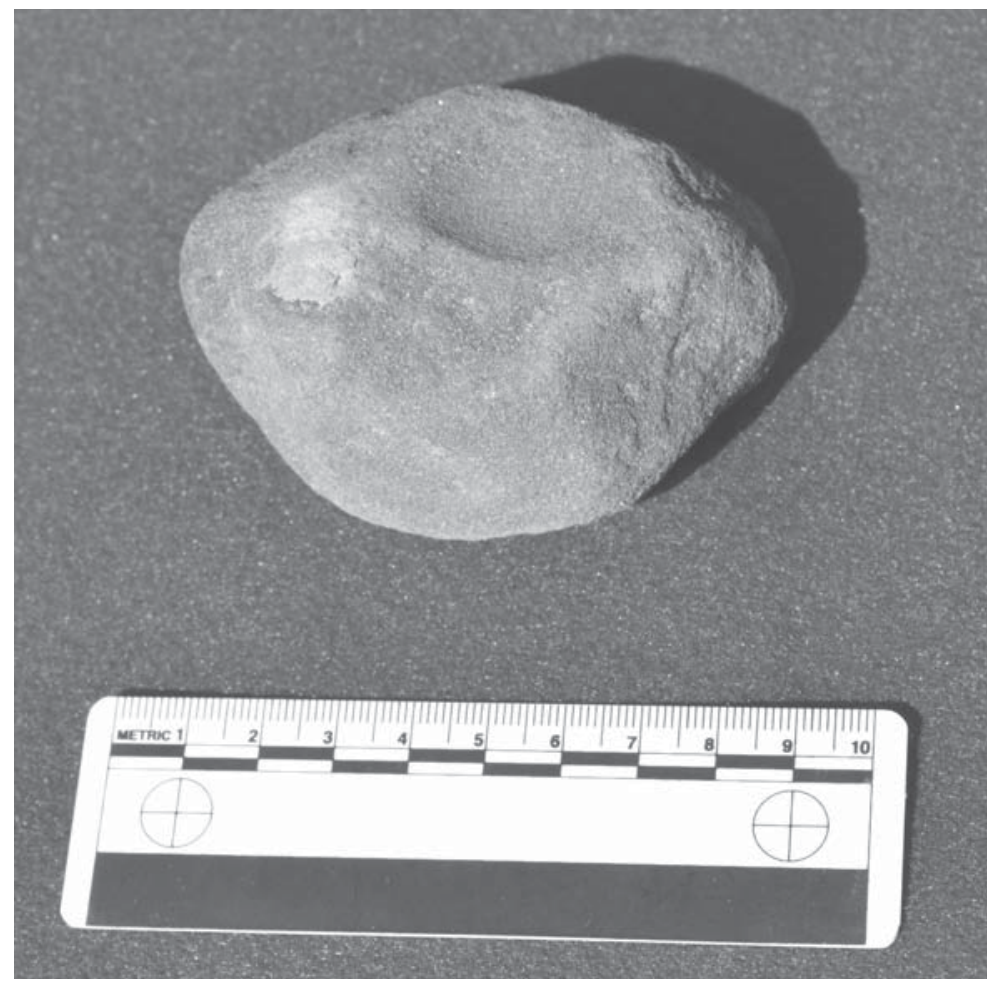

Figure 1. Dead Cow site (41SM324) ferruginous sandstone nutting stone.

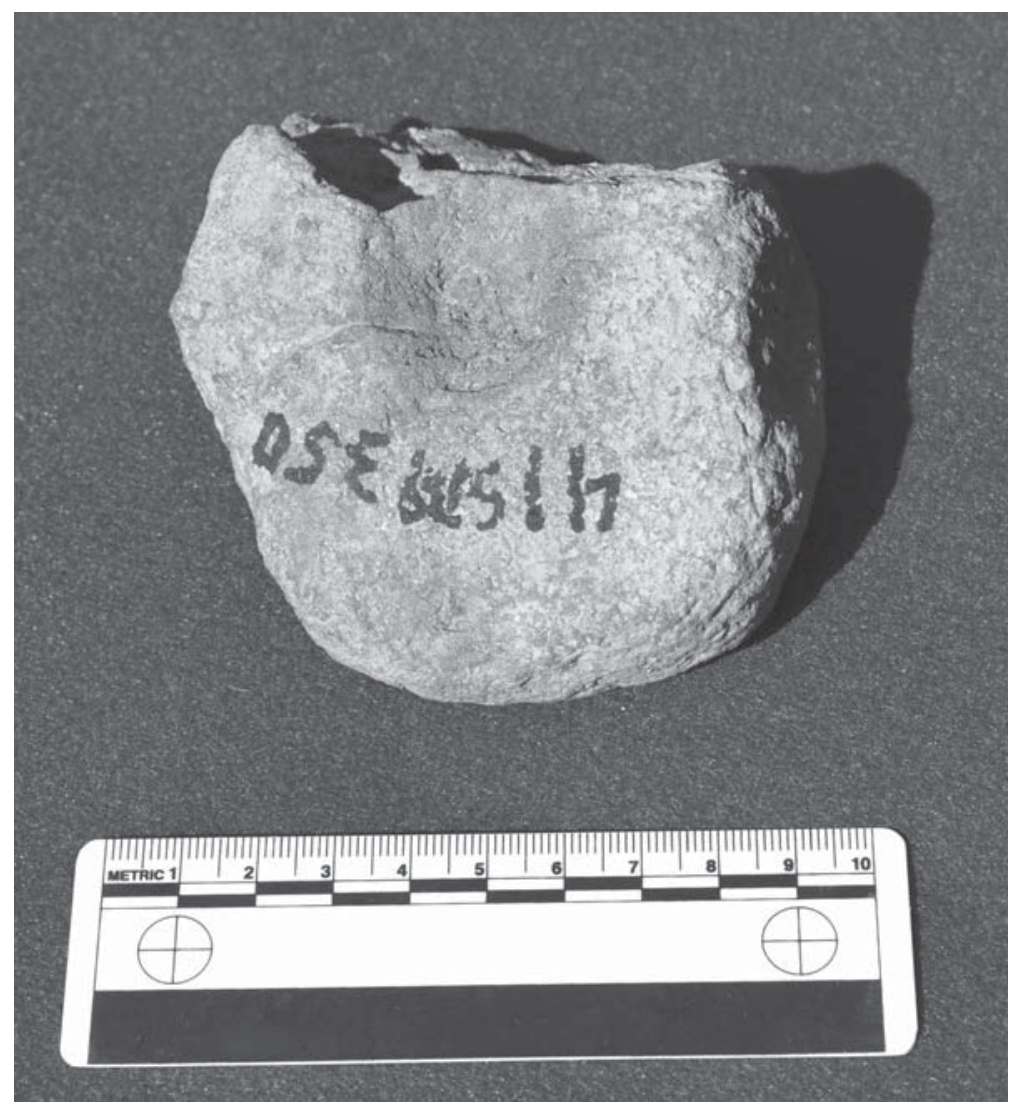

Figure 2. 41SM350 ferruginous sandstone nutting stone. 


\section{SM358}

This is also an undated Caddo habitation site in eastern Smith County, Texas. A FSS nutting stone was found there in ST 9, between 0-20 cm bs. Both sides of the stone are smoothed but the edges appear unmodified. The length is $8.0 \mathrm{~cm}$, width $7.1 \mathrm{~cm}$, and thickness $3.0 \mathrm{~cm}$ (Figure 3). It has a shallow $3.5 \mathrm{~cm}$ diameter depression on one side.

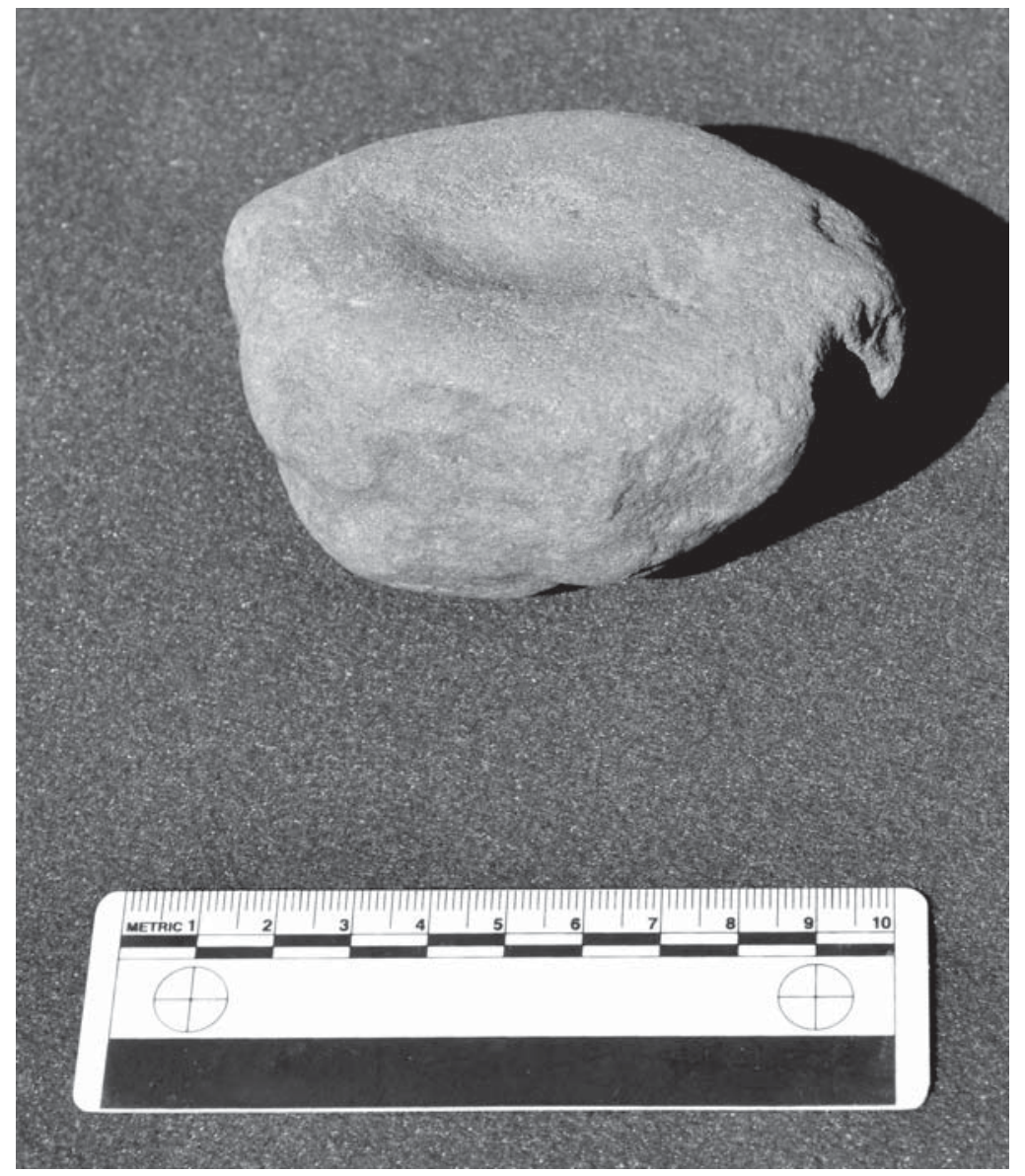

Figure 3.41SM358 ferruginous sandstone nutting stone.

\section{Leaning Rock (41SM325)}

Leaning Rock is a 14th century Caddo habitation site located in the eastern portion of Smith County, Texas (Walters 2008:24-27). This nutting stone, from Unit 5, 19-26 cm bs, is a FSS nutting stone, with a weight of $490.0 \mathrm{~g}$, that was located along with numerous fire-cracked rock and ground stone tools adjacent to Feature 1, a hearth. Length is $10.0 \mathrm{~cm}$, width $7.0 \mathrm{~cm}$, and thickness $4.0 \mathrm{~cm}$. One side is smooth with a shallow $2.5 \mathrm{~cm}$ circular depression (Figure 4).

\section{Pilgrim's Pride (41CP304)}

The Pilgrim's Pride site is a large prehistoric Caddo site in the Big Cypress Creek drainage in Camp County, Texas (Perttula 2005:1). Item 5 is a surface find in Area VIII and is described as a nutting stone constructed of fine-grained FSS weighing $950 \mathrm{~g}$. It is $16.0 \mathrm{~cm}$ in length, $11.0 \mathrm{~cm}$ in width, and $10.0 \mathrm{~cm}$ thick (Figure 5). According to Walters (2005:216-218): 


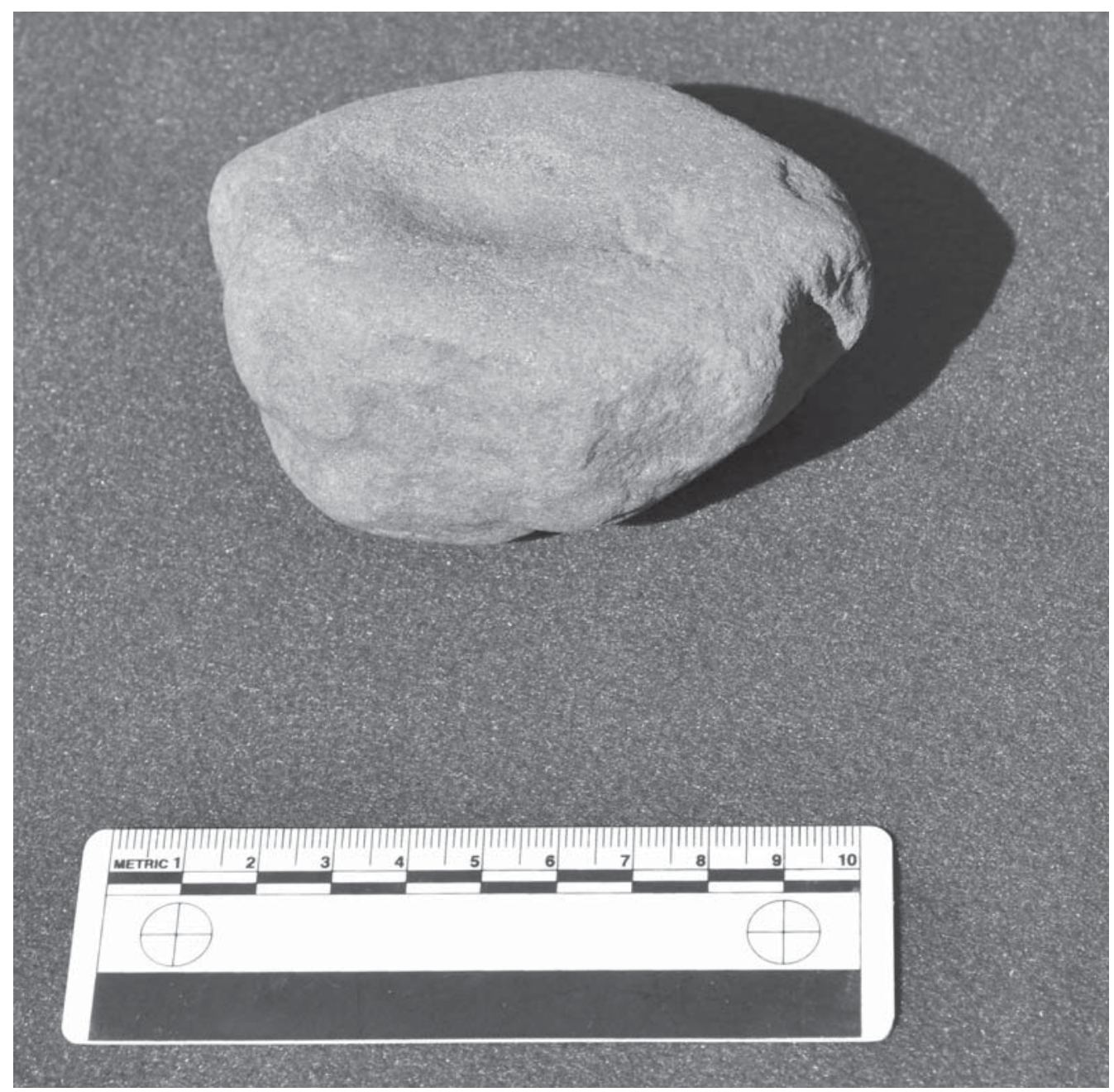

Figure 4. Leaning Rock (41SM325) ferruginous sandstone nutting stone.

The large pitted stone has two circular depressions on one surface, and three on the opposing surface. The pitted depressions range from 12.6-32.0 $\mathrm{mm}$ in diameter and 5.0-11.5 $\mathrm{mm}$ in depth. The lack of pulverized grains, the absence of linear striations, and no difference in color between the pit and the stone's surface suggest that bipolar flaking formed these pits, not nut cracking.

\section{Walters Farm (41SM194)}

The Walters Farm site is located in eastern Smith County. It is a component of what Walters (2006:42) has termed the Browning phase, a Middle Archaic culture that was highland-oriented; with sites occurring in upland settings, usually long distances from water; having Middle Archaic points made usually of exotic cherts; and ground stone tools (Walters 2006:42). This nutting stone (Figure 6) is a fine-grained, dense FSS, and was found on the surface. This material is often referred to as hematite in the archaeological literature. The material, workmanship, and appearance closely resemble grooved stone axes that are associated with Middle and Late Archaic sites across East Texas (Turner 2006:1-32). This stone already exhibits the peeling effect that characterizes tools made from this material. The nutting stone is $18.5 \mathrm{~cm}$ in length, $18.0 \mathrm{~cm}$ in width and $6.0 \mathrm{~cm}$ thick; top and bottom surfaces are slightly concave, very smooth, and both surfaces have circular $3.5 \mathrm{~cm}$ diameter polished depressions (Figure 6). In contrast to the other examples reported herein, this stone exhibits much finer workmanship. Perhaps it is part of the same toolkit as the grooved stone axes, as they exhibit the same fine workmanship, but that remains unknown at present. 


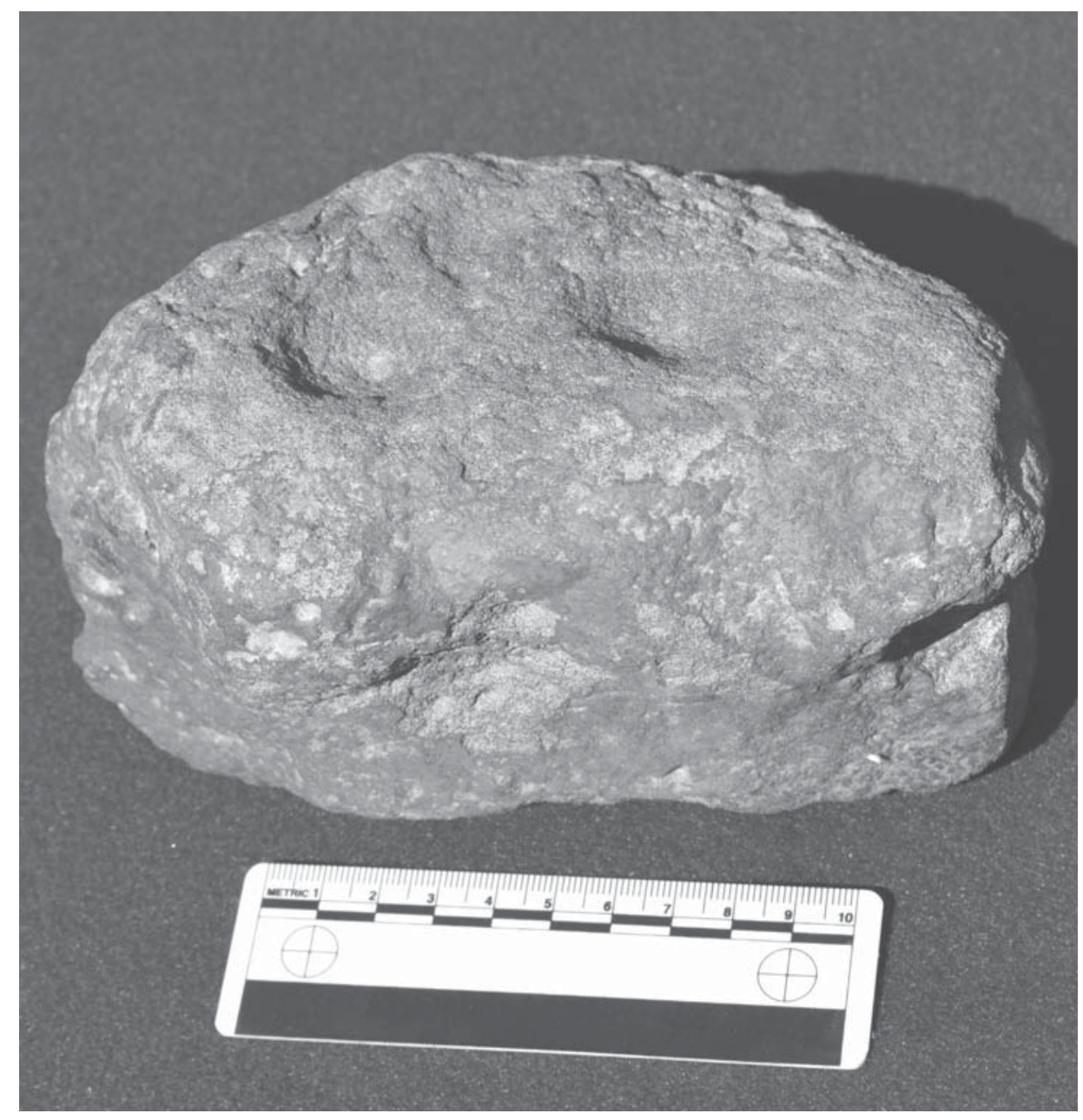

Figure 5. The Pilgrim's Pride site (41CP304) ferruginous sandstone nutting stone.

\section{METHODOLOGY}

The goal of this study was to identify nuts or other processed plant material on these nutting stones. They were submitted to Dr. Steven Bozarth, University of Kansas Palynology Laboratory, for analysis. In this discussion we summarize Bozarth's report; a full copy is available from the authors.

Phytoliths are formed as microscopic molds of the interior of plant cell walls. Growing plants typically absorb water containing dissolved silica through their roots. Microscopic silica bodies are subsequently produced by the precipitation of hydrated silicon dioxide $\left(\mathrm{SiO}_{2}\right)$ within the plant's cells, cell walls, and intercellular spaces. Silica bodies that have characteristic shapes and sizes are called opal phytoliths (Wilding and Drees 1971). The term phytolith is derived from the Greek words phyton, meaning plant, and lithos, meaning stone. Opal is the common name for amorphous, hydrated, silica dioxide. Opaline bodies formed in plants without specific shapes are simply plant opal.

Phytoliths form in most plants and are produced in a multitude of shapes and sizes. Many phytolith types are specific to particular groups of plants. A phytolith type is considered "characteristic" if it is common in one specific taxon but also produced in very limited amounts in one or more other taxa. A phytolith type is "diagnostic" if its shape and/or size are specific to a particular taxon. Fortunately, many phytoliths are resistant to weathering and are preserved in most soils for long periods of time. Because phytoliths are formed primarily in the vegetative parts of plants and are released on soil surfaces when the plant decays, a large proportion of the phytolith record represents localized deposition (Piperno 1988). 


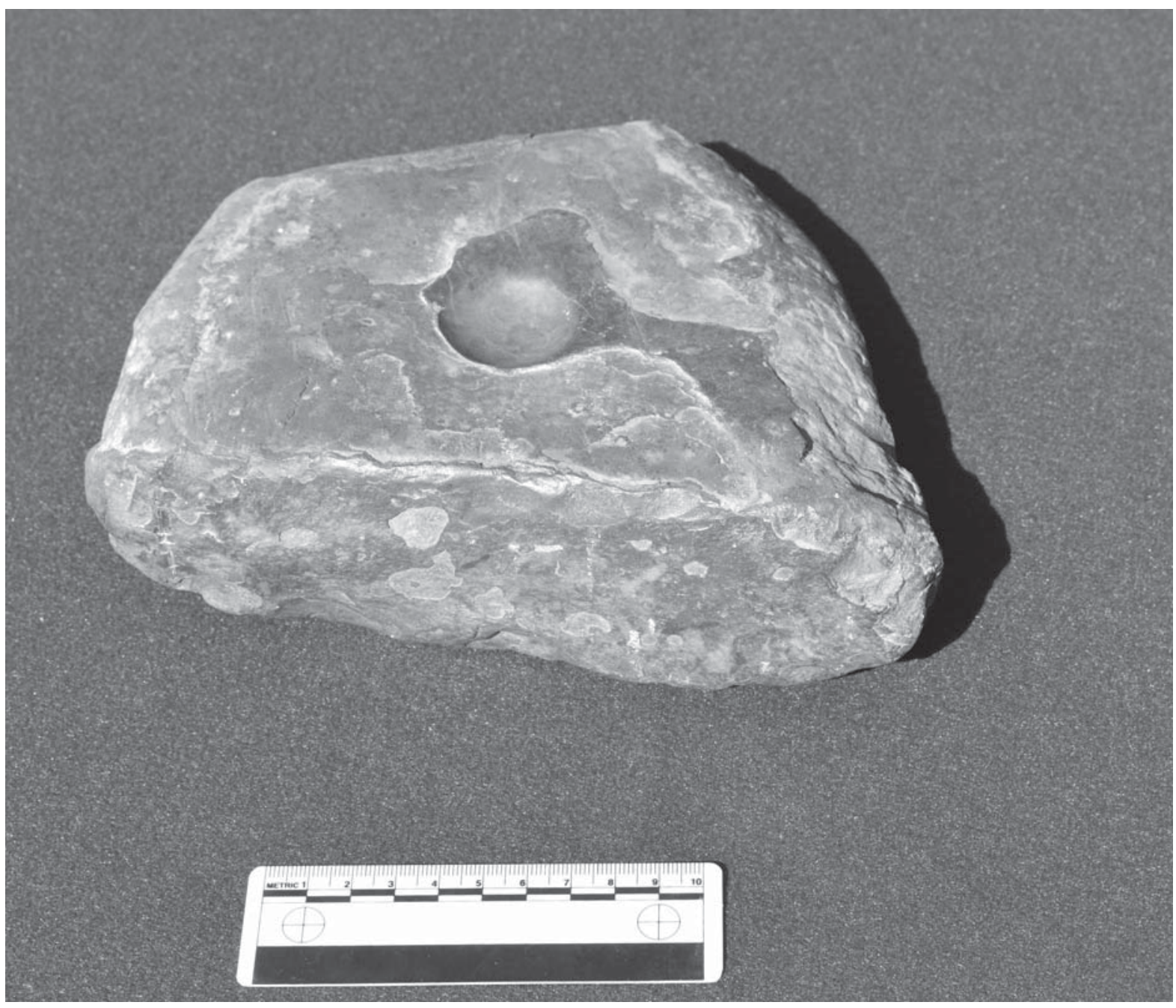

Figure 6. Walters Farm (41SM194) ferruginous sandstone nutting stone.

The nutting stones from the East Texas sites were processed for phytoliths. A sonic scrubber was used to clean the depressions. These small sediment samples were floated with zinc bromide concentrated to a specific gravity of 2.3 to separate phytoliths from the heavier clastic mineral fraction. These isolates were then washed with reverse osmosis water and dehydrated with butanol and stored in 1-dram glass vials.

Isolates from three nutting stones (41SM194, 41SM324, and 41SM358) were mounted on microscope slides in immersion oil under $22 \times 40 \mathrm{~mm}$ cover glasses and sealed with clear nail lacquer. All of the phytoliths in each isolate were analyzed at a magnification of $625 \mathrm{X}$ with a petrographic Zeiss microscope (Table 1).

Phytoliths were taxonomically classified according to a convention that has been developed and used in other reports and publications. An extensive reference collection of plants native to the Great Plains has been developed in the palynology laboratory through field collection, research plots, solicited samples, and specimens supplied by the University of Kansas Herbarium. The phytolith reference collection consists of phytoliths extracted from complete or representative aerial portions of the following: (1) 25 species of 20 genera of 11 tribes of six subfamilies of the Poaceae (grass); (2) 11 species of four genera of four non-grass monocot families; (3) 65 species of 62 genera of 11 families of herbaceous dicots; (4) 20 species of 18 genera of 13 families of woody (mostly arboreal) dicots; (5) 14 species of seven genera of five families of gymnosperms; and (6) two species of Equisetum. 
Table 1. Biosilicate Frequencies of Nutting Stones from 41SM194, 41SM324, and 41SM358.

\begin{tabular}{lccc}
\hline Site & 41 SM194 & 41 SM324 & 41 Su358 \\
Depth (cmbs) & surface & 42 & $0-20 \mathrm{cmbs}$ \\
Phytolith Sum & 118 & & 25 \\
& & 2.4 & - \\
Grass genera/subfamilies & - & 4.8 & 16 \\
Aristida & $20.3\{1\}$ & 21.4 & 24 \\
$\quad$ Pooids & 22 & 4.8 & - \\
Chloridoids & $10.2\{1\}$ & & - \\
Panicoids & 0.8 & 2.4 & 48 \\
Grass inflorescence/seeds & & & - \\
$\quad$ Deeply-lobed bodies & 29.7 & 50 & - \\
Other grass phytoliths & 11 & 11.9 & - \\
$\quad$ Long cells & 3.4 & - & - \\
Bulliform & - & - & - \\
$\quad$ Trichomes & & - & \\
Asteraceae & 0.8 & 2.4 & \\
Trees and shrubs & 0.8 & & \\
$\quad$ Spheres w/ occluded carbon & 0.8 & & \\
$\quad$ Smooth spheres & Diatoms & &
\end{tabular}

East Texas nutting stones biosilicates data \{charred phytoliths\}

\section{RESULTS AND DISCUSSION}

Phytoliths and diatoms were well-preserved in all three samples. Ten types of phytoliths were identified, in addition to rare occurrences of diatoms. Moreover, a re-examination of phytolith reference slides of shagbark hickory nuts and black walnuts show that both produce taxonomically useful phytoliths. The endocarp and kernel of black walnuts produce numerous small crystals. The shell and flesh of shagbark hickory produce numerous thin birefringent plates.

No evidence of nuts or other edible plant material, including maize, was found. However, absence of phytoliths from black walnuts and shellbark hickory, both present in the study area, does not necessary mean that these nuts were not processed. These nut shells are hard and as such their phytoliths would not have been ground into the nutting stones just by cracking the nuts. Thus, finding phytoliths from nuts on nutting stones is inherently difficult.

\section{REFERENCES CITED}

Davis, D., Jr.

1995 Prehistoric Artifacts of Texas Indians. Pecos Publishing Co., Ft. Sumner, New Mexico.

Perttula, T. K.

2011 Early to Mid-19th Century Occupation at the Dead Cow Site (41SM324), Smith County, Texas. Journal of Northeast Texas Archaeology 34:31-34. 
Perttula, T. K. (editor)

2005 Archeological Investigations at the Pilgrim's Pride Site (41CP304), a Titus Phase Community in the Big Cypress Creek Basin, Camp County, Texas. 2 Vols. Report of Investigations No. 30. Archeological \& Environmental Consultants, LLC, Austin.

Piperno, D. R.

1988 Phytolith Analysis-An Archaeological and Geological Perspective. Academic Press, Inc., New York.

Turner, R. L.

2006 Hematite Axes of Northeast Texas. Bulletin of the Texas Archeological Society 77:1-32.

Walters, $\mathrm{M}$.

2005 Groundstone Tools from Area VIII. In Archeological Investigations at the Pilgrim's Pride Site (41CP304), a Titus Phase Community in the Big Cypress Creek Basin, Camp County, Texas, edited by T. K. Perttula, pp. 216-219. 2 Vols. Report of Investigations No. 30. Archeological \& Environmental Consultants, LLC, Austin.

2006 Walters Farm, Smith County, Texas. Journal of Northeast Texas Archaeology 25:40-56.

2008 Life on Jackson Creek, Smith County, Texas: Archeological Investigations of a 14th Century Caddo Domicile at the Leaning Rock Site (41SM325). Caddo Archeology Journal 17:1-119.

Wilding, L. P. and L. R. Drees

1971 Biogenic Opal in Ohio Soils. Proceedings of the Soil Science Society of America 35:1004-1010. 